\section{THE IMPORTANCE OF BALANCE FOR THE PERFORMING THE MAJOR OUTER REAP THROW TECHNIQUE}

\section{ZNAČAJ RAVNOTEŽE ZA IZVOĐENJE TEHNIKE BACANJA IZBIJANJEM NOGE OTPOZADI}

\section{SUMMARY}

The aim of the research is to determine the relation of balance as a motor ability with the performance of the major outer reap throw technique (according to the program of special physical education-SPE), for a possible modification of mentioned training technique and selection of appropriate resources to improve the same. The study was conducted on a sample of 67 male subjects. The sample of variables consisted of eight standard tests for the evaluation of the balance of motor ability, and the variable for assessing the level of adoption of the major outer reap throw technique from the SPE program. Analyzing the results, obtained by regression analysis, it was found that there was no statistically significant correlation between variables for balance assessment and the efficiency of major outer reap throw technique. Since the statistically significant correlation between applied test for the balance evaluation and the observed technique performance was not found, it seems necessary that in similar future studies specific and consistent tests, which more accurately explain the dependence between the balance and the quality of a major outer reap throw technique, should be constructed or selected.

Keywords: Balance, technique of performance, connectivity

\section{Darko Paspalj ${ }^{1}$ and Milan Gužvica ${ }^{1}$}

${ }^{1}$ Faculty of Security Science, University of Banjaluka, Bosnia and Herzegovina

Original scientific paper doi:10.5550/sgia.171301.en.PG

UDC: 796.433 .012 .266

Received: 06.05.2017. Accepted: 26.06.2017.

Correspondence author: Darko Paspalj,PhD Faculty of Security Sciencess, University of Banja Luka Bulevar vojvode Živojina Mišića 10 a, 78000 Banja Luka Bosnia i Herzegovina Tel:+387 51333603 +38765906325 dpaspalj@yahoo.com

Sportlogia 2017, 13 (1), 18-28. E-ISSN 1986-6119 COBISS.RS-ID 6768408 


\section{INTRODUCTION}

The technique of program contents of the SPE represents the system of rational movements and trends that are manifested in the current levels of adoption, such as typical movements, blocks, kicks, throws, sweeping and joint locks (Guzvica, 2006) whereby, among other abilities and characteristics, motor skills have great significance. Performing these techniques causes certain movements in space and time, with certain segments of the body changing its relative position, and therefore disturbs the balance. Sekulic \& Metikos (2007) found that the balance is the ability of keeping the body in a certain position during inaction, but also the ability to quickly establish a stable position of the whole body in a variety of movements and trends. Nicin (2000) concludes that the balance is a basic motor ability to maintain the body in a balanced position (position) which depends on many factors, of which the most important are: genetic determinism, the state of the brain balance center, the condition of the vestibular apparatus, age, bearing surface, the height of the center of gravity of the body, the number of motor habits and training, etc. In mechanics, it is the balance positions which are classified according to the behavior of the body under the influence of forces that tend to change their position, while most of the human body position is maintained by active muscular forces (Jaric, 1997). Due to the fact that the balance is ability to preserve a stable position of the body in a variety of motion (movement) and position, that is the ability to retain the body in a given position, we distinguish between static and dynamic balance. Static balance refers to the maintenance of a specified position at a stand-still, where default position should be maintained by static stress (bearing surface is fixed) whereas dynamic balance implies the ability to maintain a stable body position that is in motion (activities in which fast changes in the position of the body in space are often carried out) during which it often comes to the change of the surface of the body support. Kosinac (2009) considers that a good balance requires good integrated nervous system with adequate afferent input, moving joints and healthy muscles, wherein the disorder of any of these factors reduces the ability to maintain the balance. According to him, sensory information have a key role in all movements, i.e. contractions of $\alpha$-motoneurons, which means that they have a key role in posture. Activities of $\alpha$-motoneurons can directly modify only the sensible signals from the peripheral receptors and command signals of the descending brain pathways. Precisely these sensing signals from the peripheral receptors belong to the control mechanisms of body posture, because the center of gravity is located in the cerebellum, where in turn it is necessary to maintain the balance of the vestibular somato- sensory system. This is important because information about the disrupted balance come from the vestibular apparatus to the cerebellum, where the actual program of correction is made, from which a quick response follows through adequate movements that aim to restore as soon as possible a stable balance position of the body, which means that sub-vestibular apparatus and the cerebellum are an important regulator of muscle tone (ibid). In the research that was conducted by Golab, 1962 (per Zaciorski), it was found that the static and dynamic balance with each other very little correlated. It was also established that, while maintaining a stable balance position, the human body is not absolutely motionless, but it is all the time, "balancing", and no matter that this movement is not characterized by the parameters of locomotion (amplitudes are very small and often unnoticed) it is conducted in the joints that are near the surface of the support. From this arises the need to differentiate the ability of maintaining its balance position according to the way of application of force, the manner of using the optic analyzer, and the size of the surface on which the balance is maintained. The stability of the body in the standby mode depends on the body weight, the force of muscles which maintain the stability, as well as the surface of the support, wherein the

Paspalj, D.\&Gužvica, M. : The importance of balance...Sportlogia 2017, 13 (1), 18-28. Page 19. 
technique performer is in a balance position as long as an external force which acts on it (torque header) is smaller than the moment of the gravitational force of one who attacks it (Kules, 2008). The dynamic indication of the stability of the balance position in one position is expressed by the angle formed by the angle of the safety which is formed by the projection of the general center of gravity of the body and the outer edge of the support surface, wherein the safety angle increases with the safety support surface and by lowering the general center of gravity (OCT). This leads us to the conclusion that the larger is the angle, the body is better balanced, which means that the techniques performer can preserve its balance until projection of OCT has travelled outside its supporting surface (Jaric, 1997). When realizing the movement and the movement characteristic of the program of SPE it is very important to emphasize that they begin and end in a stable balance, where the center of gravity of the body is above the surface of the support. However, due to not enough "strength" in the muscle and joint system, balancing is done mostly unknowingly with some compensatory movement and the important role of antagonist muscles. Of course, when the center of gravity of the body is located below the surface of the support, then there is no problem with balance, because the balance position is held by gravitational forces and without the active participation of muscles. Within the current program the Faculty of Security Science University of Banja Luka, as part of the SPE, to the level of utilitarianism, among other techniques, are taught throwing techniques of judo that in terms of biomechanical method of the embodiments can be divided into: throwing techniques by cleaning (de ashibarai and okuriashibarai), throwing techniques by outbreak (o sotogari and haraigoshi), throwing techniques by coverage (ipponseoinage, koshiguruma, ogoshi and morotegari) and throwing techniques by block (sasaetsuricomiashi and tai otoshi ). In the SPE, throwing techniques are complex movement structures designed primarily for the destabilization and the infliction of the pain to the "opponent" on the way of establishing complete control over him. The techniques are usually performed in self-defense, as a technique to counter-attack (although they can be applied in direct attack). The efficiency of their realization depends on the timeliness of commencement, duration of the performance and the control before, during and after their implementation. The techniques are carried out after the capture of the opponent's body or parts of the opponent's body, by transferring its own motion to an opponent's body (Arlov, 2001). Drid (2005) states that during the mutual struggle in mutual attacks more successful is the one who is conversant with the technique, who knows to maintain so its own balance, while at the same time disrupts the opponent's balance and uses his errors when performing certain attacks or operations. It has already been mentioned that the success of throwing is determined by strength, speed, timing and accuracy, whereby it is very important that the position of his body is adjusted to the position of the opponent's body, to perform the throw by using the smallest possible energy power. Thus, the performance of the throw is done at high speed, whereby it is possible to single out the following phases: phase of upsetting the balance of the opponent, the phase of establishing contact with the opponent and the phase of implementation of the throw. All these phases are interrelated and form one unit, whereby the efficiency of their implementation dependent on precise and rapid (explosive) performance of all phases (Milosevic, 2013). Each of these phases is characterized by a specific movement (trajectories of individual body segments) with maximum mutual dependence. Distortion of your opponent's balance aims to create favorable conditions for carrying out an imaginary technique, where the most important thing is that the projection of the body center of gravity of the opponent is removed as much of the surface of the support center, which is usually performed in the movement by using the inertial force and the weight of it (pulling or pushing) and depends on the reaction and movement of it (ibid). Achieving the contact with an opponent can be performed in all these directions, where the performance

Paspalj, D.\&Gužvica, M. : The importance of balance...Sportlogia 2017, 13 (1), 18-28. Page 20. 
technique requires quick implementation so the opponent would not return to the balance position. According to the first principle the throwing is performed by rotating the body of performer around the point of blocking (foot, lower leg, knee, thigh and hips), and according to the second, by turning the performer's body through a balanced oppositely to the direction of the force. Thus, it should be noted that if the arm torque is higher or the turnstile is lower, the torque rotation will be higher, because the attacker's force is increased by the component of gravity. For the efficiency of the performance of techniques of throwing with outbreak of the stein leg it is essential that the opponent's center of gravity projection falls in point of support, thus the possibility of its resistance reduced to the passive static resistance (ibid). From the above we see that the efficiency of throws in the first instance depends on the instability of the opponent's balance and correctly carried out the preparatory movements for pitching (which requires a stable balance position of the performer) which requires clarification of the importance of the balance in the application of the outer reap throw technique in the SPE program. The reason why this technique has its own respective application in the SPE program is that the initial phase of the throw-off pushing the opponent backwards, wherein the direct and quick entry into this roll allows the body weight of the performer to be transmitted to the opponent's why he loses the balance because there is no visual contact with the direction in which he moves, and it is therefore more difficult to re-establish the position of stable balance and organize the defense. Like almost all other throwing techniques and the technique of the outer reap throw is characterized by three stages: the stage of disrupting the balance of the opponent, the phase of the establishment of the contact with the opponent and the phase of the pitch. All these phases are interrelated and form one unit, with the efficiency of their implementation dependent upon precise and rapid (explosive) performance of all the phases (ibid). Each of these phases is characterized by a specific movement (trajectories of individual body segments) with maximum mutual dependence. The throw is taken from the basic attitude and right guard at the moment when the opponent pulls or pushes (in our case, when the opponent pulls toward you), so as to step right foot backwards withdrawing the performer to himself disturbing his balance. At the time of the balance disturbance the performer reflex action tries to maintain a stable balance by carrying out a step with the left foot forward into the left side for about 15 to $20 \mathrm{~cm}$ from the opponent's right foot, which is fully transferred weight to the left leg and stabilize the balance position. In the following activities the performer simultaneously pulls the left hand of the opponent's right hand toward the belt and pushes the right hand of the opponent's left shoulder and the left side of the body to the left, and thus disturbs the balance of the opponent. Furthermore, by strong twisting of the body in the outside in the angle of 45 degrees (continuous contact with the opponent) on the opponent leads to no balance position, reducing its surface support (causing him to stand on the outside of the right foot). Further action is by rotating the pelvis to the left the performer performs swinging right foot forward (behind the opponent's right leg, so that the head and the fingers of his right leg in the same plane), followed by simultaneously bending the body forward and downward, strong momentum of the same (by half) back foot makes contact in the crook of the knee of the opponent's right leg, knocking his leg back and up. The performer by synchronizing and powerful dragging of his left hand to her right hand and pushing down throws the opponent in front of him (directing him, while so that he falls on the left side of the body surface). It is very important that at the outbreak of the opponent's leg the performer maintains the stable balance. This is achieved in the way that the entire weight of the body transfers to the front of the foot of the stein leg, which allows him to fully control the opponent's decline to the ground. Experience has shown that, in these circumstances it is very complex and important for learning and adoption of motor programs

Paspalj, D.\&Gužvica, M. : The importance of balance...Sportlogia 2017, 13 (1), 18-28. Page 21. 
from SPE to maintain a stable balance position, and that is why the balance is the subject of our research. In this regard, the goal of the research is to investigate the relation of balance as the motor ability with the performance of major outer reaps throw technique from the SPE program, for a possible modification of that training technique and selecting appropriate resources to improve the same.

\section{METHODS}

Overall education of outer reap throwing technique lasted six teacher's hours during three weeks, and was accomplished during the ordinary classes with the first-year students of The Faculty of security science during the second semester in the cabinet of martial arts of the Faculty of Physical education and sport in Banja Luka. The efficiency of performing the outer reap throwing technique was determined by an expert evaluation by five examiners (experts for SPE). Techniques were performed three times each, where subjects were turned sideways in relation to the testers. Application of the evaluation required a certain preparation of evaluators for the evaluation, in which evaluators, in order to harmonize the criteria of assessment, a film was shown for the presentation of outer reap throw techniques of the stein leg from behind and shown a diagram with certain stages that needed particular attention: getting out of balance, the establishment of the contact, entering the appropriate position for throwing and throwing performance.

The sample consisted of sixty-seven students (67) of the first year of the Faculty of Security Science in Banja Luka, male. The subject represented a population of physically active persons, aged $19 \pm 0.6$ years, clinically healthy, with no visible physical defects or morphological abnormalities. Basic antropomorphological indicators of the tested samples were as follows: TV $=181,40$ $\pm 5,90 \mathrm{~cm}, \mathrm{TM} 78,60 \pm 10,18 \mathrm{~kg}$ i BMI $23,87 \pm 2,51$. The sample of variables in this study is divided into the predictor variables and the criterion variable. Sample predictor variables consisted of a set from8 tested in practice-implemented variables to assess the capability of maintaining a balance: MBAU20 (standing on two legs longitudinally on the bench for balance with eyes open), MBAU10 (standing on one leg longitudinally on the bench for balance with eyes open) MBAP20 (standing on two legs cross on the bench for balance with eyes open), MBAP10 (standing on one foot cross on the bench for balance with eyes open), MBAU2Z (standing on two legs longitudinally on the bench for balance with your eyes closed), MBAU1Z (standing on one leg longitudinally on the bench for balance with your eyes closed), MBAP2Z (standing on two legs cross on the bench for balance with your eyes closed), MBAP1Z (standing on one foot cross on the bench for balance with your eyes closed). All variables to assess motor skills - balance possess the necessary metric characteristics (Metikos, Hofman, Prot, Pintar \& Oreb, 1989).

The criterion variable was the assessment on taking the outer reap throw, and was formed by the average score of the five experts who teach SPE-e in a scale of 5.00 to 10.00. The criterion of evaluation was as follows:

The rating of 10 (ten) was assigned for perfect constructive throwing technique, in the optimal rhythm, which satisfies the basic principles of biomechanics and enables a safe and complete control.

Rating 9 (nine) was assigned for excellent performance techniques or correct, without any technical errors, constructive technique, with adequate power, speed and amplitude throws performed.

Rating 8 (eight) was assigned for the throw that, technically, it's not entirely true implemented or not implemented strongly, fast enough, the opponent did not have sufficient amplitude of

Paspalj, D.\&Gužvica, M. : The importance of balance...Sportlogia 2017, 13 (1), 18-28. Page 22. 
fall, or if the performer made a mistake in the correct performance of techniques, as an insufficient ejection of the opponent off balance or improper contact with the body of an opponent.

Grade 7 (seven) was assigned to toss that was carried out by at least two errors or if the throw was performed with insufficient amplitude or that they were not truly and well performed two of the three phases of the throw: getting out of balance, making contact with an opponent and the final phase of the throw.

Ratings of 6 (six) was assigned for the throw, with the apparent faults in the art embodiment. By this is meant the apparent lack of or incorrect performance of one of the first two phases throws (pull-out of balance and making contact) and the lack or incorrect performance of a segment of the throw. This means that throwing is not carried out by an adequate force and speed, and has the necessary amplitude of the fall, but there are at least two phases of the throw, and as such can be recognized.

Rating 5 (five) was assigned to toss that do not fully meet the basic technical characteristics of the respective throws. Throwing is not done fast and strong enough; neither opponent has the necessary amplitude of the fall. At the same time, the correct throwing out two out of three phases of throws (or are badly implemented).

All data were analyzed by methods of descriptive and comparative statistics. From the field of descriptive statistics, for each variable measures of central tendency (arithmetic average) and measures of dispersion (standard deviation) were calculated, whereas the test for normal distribution of the results applied Kolmogorov - Smirnov test. To determine the qualitative correlation between predictor and criterion variable regression analysis was applied. All statistical calculations were performed using SPSS statistical software application (version 20.00).

\section{RESULTS}

Table 1. Descriptive indicators of predictor variables and the criterion variable

\begin{tabular}{lcccc}
\hline Variables & $\mathrm{N}$ & Mean & Std. Deviation & KS (p) \\
\hline MBAU20 & 67 & 3.43 & 1.76 & .19 \\
\hline MBAU10 & 67 & 11.67 & 10.48 & .29 \\
\hline MBAP20 & 67 & 6.14 & 5.77 & .31 \\
\hline MBAP10 & 67 & 4.05 & 3.17 & .23 \\
\hline MBAU2Z & 67 & 2.53 & 1.32 & .25 \\
\hline MBAU1Z & 67 & 2.97 & 1.03 & .29 \\
\hline MBAP2Z & 67 & 2.37 & .79 & .20 \\
\hline MBAP1Z & 67 & 2.00 & & \\
\hline
\end{tabular}

Paspalj, D.\&Gužvica, M. : The importance of balance... Sportlogia 2017, 13 (1), 18-28. Page 23. 
Legend:N - number of respondents; Mean - mean; Std. Deviation - standard deviation; KS(p) - KolmogorovSmirnov test of probability; MBAU20 - standing on two legs longitudinally on the bench for balance with open eyes, MBAU10 - standing on one leg longitudinally on the bench for balance with open eyes, MBAP20 - standing on two legs cross on the bench for balance with open eyes, MBAP10 - standing on one leg cross on the bench for balance with open eyes, MBAU2Z- standing on two legs longitudinally on the bench for balance with your eyes closed, MBAU1Z - standing on one leg longitudinally on the bench for balance with your eyes closed, MBAP2Z - standing on two legs cross on the bench to balance with your eyes closed, MBAP1Z - standing on one leg cross on the bench for balance with your eyes closed, TBINOT - throwing technique with the outbreak of legs from behind.

Table 1 shows the descriptive statistics of the measures used to assess balance motor skills, as well as measures which evaluated the efficiency of the technique of the outer reap throwing technique. Table 1. The results of Kolmogorov-Smirnov test match the normality schedule of the results. Average evaluation of efficiency of a outer reap throwing technique is 6.82 .

Tables 2 and 3 show the relationship between the dependent variable throw discharge stein rear legs (TBINOT) and the associated independent variables for the evaluation of motor abilities balance.

Table 2 Parameters of multiple regressions of motor skills balance for variable TBINOT

\begin{tabular}{cccc}
\hline $\mathrm{R}$ & $\mathrm{R}^{2}$ & $\begin{array}{c}\text { The standard error of } \\
\text { assessment }\end{array}$ & $\mathrm{F}$ \\
\hline $.351^{\mathrm{a}}$ & 1.028 & 1.017 & .434 \\
\hline $\begin{array}{l}\text { a Predictors (Constans) MBAU2O, MBAU1O, MBAP2O, MBAP1O,MBAU2Z, MBAU1Z, MBAP2Z, MBAP1Z } \\
\text { b Dependent varijable TBINOT }\end{array}$
\end{tabular}

Table 3 The regression coefficients motor skills balance for variable TBINOT

\begin{tabular}{|c|c|c|c|c|c|c|}
\hline & \multirow[t]{2}{*}{ Model } & \multicolumn{2}{|c|}{ Non-standardized coefficients } & $\begin{array}{l}\text { standardized } \\
\text { coefficients }\end{array}$ & \multirow[t]{2}{*}{$\mathrm{t}$} & \multirow[t]{2}{*}{$\mathrm{p}$} \\
\hline & & B & $\begin{array}{c}\text { The standard } \\
\text { error }\end{array}$ & Beta & & \\
\hline \multirow{4}{*}{1} & (Constant) & 6.344 & .616 & & 10.304 & .000 \\
\hline & MBAU20 & -.070 & .078 & -.120 & -.904 & .370 \\
\hline & MBAU10 & .005 & .013 & .053 & .363 & .718 \\
\hline & MBAP20 & .012 & .026 & .068 & .473 & .638 \\
\hline
\end{tabular}

Paspalj, D.\&Gužvica, M. : The importance of balance...Sportlogia 2017, 13 (1), 18-28. Page 24. 


\begin{tabular}{cccccc}
\hline MBAP10 & -.110 & .056 & -.340 & -1.961 & .055 \\
\hline MBAU2Z & .037 & .123 & .047 & .298 & .767 \\
\hline MBAU1Z & .268 & .154 & .270 & 1.739 & .087 \\
\hline MBAP2Z & -.110 & .191 & -.085 & -.576 & .567 \\
\hline MBAP1Z & .205 & .236 & .142 & .869 & .388 \\
\hline
\end{tabular}

a. Dependent Variable: TBINOT

B - Beta coefficient; Std. Error - standard error; $\mathrm{t}$ - $\mathrm{t}$ test; $\mathrm{p}$ - statistical significance; MBAU20 - standing on two legs longitudinally on the bench for balance with open eyes, MBAU10 - standing on one leg longitudinally on the bench for balance with open eyes, MBAP20 - standing on two legs cross on the bench for balance with open eyes, MBAP10 - standing on one foot cross on the bench for balance with open eyes, MBAU2Z $\neg$ - standing on two legs longitudinally on the bench for balance with your eyes closed, MBAU1Z - standing on one leg longitudinally on the bench for balance with your eyes closed, MBAP2Z - standing on two feet cross on the bench for balance with your eyes closed, MBAP1Z - standing on one foot cross on the bench for balance with your eyes closed, TBINOT throwing technique outbreak legs from behind.

The results of the regression analyze shown in Table 2 show that there is no statistically significant qualitative relationship between the predictor and criterion variable which results in inability of the prediction of the result of outer reap throw technique according to the motoric balance ability.. Multiple correlation coefficient indicates a small approval of the dependent variable with independent variables, while the coefficient of multiple determination explains $12.3 \%$ of common variability with the criterion, whereby the value of the F-test and the achieved level of significance $(p=0.434)$, indicates the absence of predictive influence on it . The remaining $87.7 \%$ in explaining common variability can be attributed to some other anthropological characteristics and abilities that were not the subject of this research.

Table 3 shows the values of beta coefficients that provide information on the impact of individual tests for assessing motor skills balance the effectiveness of a technique of outer reap throwing stein legs.. The table shows that no single variable has no statistically significant effect on the efficiency of a technique of outer reap throwing stein from the SPE program .On the border of statistical significance (0.055) there is a variable standing on one foot cross on the bench for balance with open eyes (MBAP1O), the coefficient Beta is - 0.34, which means that this variable alone contributes most to explaining the dependent variable, when deducting The variance explained by any other variable in the model. A little smaller contribution is made variable standing on one leg longitudinally on the bench for balance with your eyes closed (MBAU1Z), the coefficient beta is 0.270 , which is also close to statistical significance $(0.087)$, while the other variables are not made a unique contribution to the prediction of dependent variable, which may be the consequence of their mutual overlapping.

\section{DISCUSSION}

Average evaluation of an outer reap throwing technique is 6.82 . The reason for this achievement of construction techniques can be found in a relatively small number of hours of

Paspalj, D.\&Gužvica, M. : The importance of balance... Sportlogia 2017, 13 (1), 18-28. Page 25. 
training, which is why students were not able to carry out the optimum number of its repetition. The available number of hours not only that they did not provide for the adoption of outward form of a technique, but also the acquisition of the inner form that includes the optimum dynamics and kinematics given criteria provided for its implementation. Furthermore, if one takes into account the complexity of the observed techniques, and its specification motor and other skills, such results is somehow expected because it comes to a complex technique that requires a high level of mobility as well as cognitive abilities. This is supported by the research that was conducted by Radjo (2001), in which he balances out as the dominant motor skills in performing outer reap throwing (o soto gari), especially at the stage of standing on one leg and the other leg sweeping. Further, he claims that in addition to motor skills (balance) cognitive processing is the most associated with the quality of performing these techniques. So, based on practical experience and previous research, we can conclude that for the effective implementation of these techniques the coordinated action of man as an integrated biological system is required (it is necessary to achieve the level of automation), which by given time available for training and previous experience of the most examinees is not objectively possible. For the results obtained by regression analysis explanation can be found in the kinematics and dynamics of the performance of observed throwing techniques. Namely, the outer reap throwing technique is carried out in accordance with the principles of biomechanics, the maximum speed and optimum level of force, wherein the segments related to certain parts of the body change .Changing the position of the parts of the body affects the change in the position of balance during which the displacement of the center of gravity of the body and the reduction of support area increased requirements for balance maintenance occurs, in which the performer must control the body position of the opponent during the fall after realized throw as well as maintaining his own balance. Because of the kinematics and dynamics of the major outer reap throw technique there is an imbalance of the body, especially in the second phase of construction where fast compensatory movements of the body and head forward are made, where the performer is on one leg (reduced bearing surface) so that his body weight is transferred to the stein leg. At this stage of the performance, there is increased requirement for balance, which is based on a system of inter-reactions of the body that are responsible for the spatial orientation of the body. For all run-time techniques of coordination and integration of information from muscles, tendons and joints reach the motor cortex and cerebellum, almost instantaneously the correction in the balance is done until they are fully stabilized. Unfortunately, in our case, using selected tests of evaluation there is the static balance for which the system that includes information from joints and vibration sensors that provide information about the position of the body at rest is largely responsible, and it is therefore understandable that we did not receive a significant effect of the balance performance on the major outer reap throw technique. Another possible reason is, above all, lack of time for training, so that we reached a relatively low level of acquisition techniques, which made a full connection of strength and coordination of the individual parts of the body of our students. Similar results were gained by Gužvica (2008) exploring the association of balance with the level of performance techniques strokes forehead fist in karate, where he found that the static and dynamic balance with each other do not correlate. Further comparing the results of this study with the results of other studies in which the balance as motor ability is researched (Metikos et al., 1989) and its significance as part of the factor structure of success in judo (Sertic 2004; Paillard, Montoyai, Dupui, 2007; Cousin, Nurkic \& Cicovic 2014). And we have obtained almost identical results.

Paspalj, D.\&Gužvica, M. : The importance of balance... Sportlogia 2017, 13 (1), 18-28. Page 26. 


\section{CONCLUSION}

On a sample of 67 male subjects aged $19 \pm 0.6$ years, the influence of balance motor ability on the efficiency of major outer reap throw technique was examined. Applied parametric statistics showed that, based on the tests with which the balance was analyzed as a significant factor for the motor programs performance, the balance as a motor ability did not appear significant for carrying out the major outer reap throw technique. Regression analysis also showed that there was no statistically significant correlation between administered tests with the quality of mentioned technique performance respectively, which indicates that in similar future studies specific tests should be constructed or selected. These specific tests would more accurately explain the dependence between the balance and the quality of the performance of major outer reaps throw technique. The assumption is that these specific tests could be helpful, not only to facilitate quicker and easier adoption of SPE training programs, but also to make them more efficient. It is considered that these tests would be of great help in the selection of candidates for admission to the Faculty of Security Science.

\section{REFERENCE}

Arlov, D. (2001). Alati samoodbrane. Novi Sad, RS: SIA.

Bratić, M., Nurkić, M., \& Cicović, B. (2014). Judo. Niš, RS: Istočno Sarajevo, BiH: Fakultet sporta i fizičkog vaspitanja, Univerzitet u Nišu i Fakultet fizičkog vaspitanja i sporta, Univerzitet u Istočnom Sarajevu.

Drid, P. (2005). Uticaj specifičnih motoričkih vježbi na efikasnost motornog učenja elementarnih džudo tehnika. Neobjavljena doktorska disertacija, Fakultet fizičke kulture, Univerzitet u Novom Sadu.

Gužvica, M. (2006). Valorizacija novog modela situaciono-motoričke obuke studenata Visoke škole unutrašnjih poslova. Doktorska disertacija. Fakultet sporta i fizičkog vaspitanja, Univerzitet u Beogradu.

Gužvica, M. (2008). Korelacija sposobnosti ravnoteže sa nivoom izvođenja tehnike udaraca čelom pesnice u karateu. Bezbjednost policija građani, (2), 59-70.

Jarić, S. (1997). Biomehanika humane lokomocije sa biomehanikom sporta. Beograd, RS: Dosije. PMCid:PMC1184399

Kosinac, Z. (2009). Igra u funkciji poticaja uspravnog stava i ravnoteže u djece razvojne dobi. Život i škola, 22 (55), $11-22$.

Kuleš, B. (2008). Trening judaša. Zagreb, RH: Kugler.

Metikoš, D., Hofman, E., Prot,F., Pintar, Ž., \& Oreb, G. (1989). Mjerenje bazičnih motoričkih dimenzija sportaša. Zagreb, RH: Fakultet za fizičku kulturu.

Milošević, M., (2013). Specijalno fizičko obrazovanje. Naučne osnove. Beograd, RS: CEDIP.

Nićin, Đ. (2000). Antropomotorika. Novi Sad, RS: Fakultet fizičke kulture, Univerzitet u Novom Sadu.

Paillard, T., Montoya, R., \& Dupui, P. (2007). Postural adaptations specific to preferred throwing techniques practiced by competition-lekel judoists. Journal of Electromyography and Kinesiology, 17(2), 241-244.

https://doi.org/10.1016/j.jelekin.2006.01.006

PMid:16563801

Rađo, I. (2001). Judo. Sarajevo, BiH: Fakultet sporta i tjelesnog odgoja. Univerzitet u Sarajevu.

Paspalj, D.\&Gužvica, M. : The importance of balance...Sportlogia 2017, 13 (1), 18-28. Page 27. 
Sekulić, D., \& Metikoš, D. (2007). Osnove transformacijskih postupaka u kineziologiji - Uvod u Osnovne Kineziološke Transformacije. Split, RH: Fakultet prirodoslovno-matematičkih znanosti i kineziologije, Sveučilište u Splitu.

Sertić, H. (2004). Osnove borilačkih sportova. Zagreb, RH: Kineziološki fakultet, Sveučilište u Zagrebu.

Zaciorski, V. M., (1975). Fizička svojstva sportiste. Beograd, RS: NIP Partizan.

Received: 06.05.2017.

Accepted: 26.06.2017.

Correspondence author:

Darko Paspalj,PhD

Faculty of Security Sciencess, University of Banja Luka

Bulevar vojvode Živojina Mišića 10 a,

78000 Banja Luka

Bosnia i Herzegovina

Tel:+38751333603

+38765906325

dpaspalj@yahoo.com

\section{SUMMARY}

The aim of the research is to determine the relation of balance as a motor ability with the performance of the major outer reap throw technique (according to the program of special physical education-SPE), for a possible modification of mentioned training technique and selection of appropriate resources to improve the same. The study was conducted on a sample of 67 male subjects. The sample of variables consisted of eight standard tests for the evaluation of the balance of motor ability, and the variable for assessing the level of adoption of the major outer reap throw technique from the SPE program. Analyzing the results, obtained by regression analysis, it was found that there was no statistically significant correlation between variables for balance assessment and the efficiency of major outer reap throw technique. Since the statistically significant correlation between applied test for the balance evaluation and the observed technique performance was not found, it seems necessary that in similar future studies specific and consistent tests, which more accurately explain the dependence between the balance and the quality of a major outer reap throw technique, should be constructed or selected.

Keywords: Balance, technique of performance, connectivity 